\title{
Destination competitiveness: how does travel experience influence choice?
}

\begin{abstract}
Traditionally, previous studies regard destination competitiveness as a static concept. More recent studies adopting a demand perspective consider competitiveness to be dynamic, with destination competitiveness varying according to tourism niche. Competitiveness also varies within tourist segments in the same niche. The authors apply the concept of travel experience to better understand destination competitiveness. Using the SCUBA diving tourism niche, the authors investigate the extent to which tourists' level of travel experience influences the importance they give to destination competitiveness attributes in a hypothetical SCUBA diving destination. Cluster analysis of results from an online survey $(n=712)$ revealed three groups with different levels of travel experience. Significant differences among the three groups were apparent in seven of ten destination competitiveness factors. The findings demonstrate the dynamism of destination competitiveness when measured from the demand perspective. Results also demonstrate that travel experience is an appropriate characteristic for classifying tourists regarding destination competitiveness attributes.
\end{abstract}

Keywords: destination competitiveness, demand, travel experience, SCUBA diving tourism

\section{Introduction}

While destination competitiveness has been studied mainly from a supplier's perspective, some recent studies have considered competitiveness from the demand viewpoint (Andrades-Caldito, Sánchez-Rivero, \& Pulido-Fernández, 2014; Pabel \& Coghlan, 2011). Research from the demand perspective studies competitiveness changes over time (Li, Pearce, \& Zhou, 2015; March, 2000; Pearce \& Lee, 2005). However, apart from Pabel and Coghlan (2011), researchers have considered only a static view in destination competitiveness studies. Investigating the importance of destination competitiveness attributes in a tourism niche and sub-niches offers a comprehensive approach to framing and ranking tourism destinations.

The impact of travel experience on travel motives of different types of tourists has been studied for over three decades (Li et al. 2015; Oppermann, 1995, 1997; Panchal \& Pearce, 2011; Pearce \& Lee, 2005; Ryan, 1998; Sonmez \& Graefe, 1998). The idea that a person's travel motivations change with more travel experience was the basis underpinning the travel career approach (formerly the travel career ladder) (Pearce, 
2005; Pearce \& Lee, 2005). Although many studies have investigated the extent to which the level of travel experience influences travel motivation, the influence of tourists' travel experience on destination competitiveness has not been studied.

Therefore, this study investigates to what extent the level of travel experience influences the importance travellers give to factors affecting the destination competitiveness of a successful SCUBA diving destination. Three groups with differing levels of travel experience evaluated and ranked the importance of ten destination competitiveness factors. We measured travel experience through the computation of two variables (number of international leisure trips and number of domestic leisure trips). Descriptive analysis, k-means cluster analysis, principal components analysis, cross-tabulation, and analysis of variance (ANOVA) were applied to data from a sample of 712 questionnaires obtained from an online survey of certified SCUBA divers.

\section{Destination competitiveness: a shift toward the demand perspective}

Initial studies of destination competitiveness (Crouch \& Ritchie, 1999; D'Hauteserre, 2000; Dwyer, Forsyth, \& Rao, 2000; Dwyer \& Kim, 2003; Enright \& Newton, 2004; Gooroochurn \& Sugiyarto, 2005; Heath, 2003; Poon, 1993) were based on economics (Porter, 1990; Wernerfelt, 1984), but more recent studies shifted toward demand (Andrades-Caldito et al. 2014; Pabel \& Coghlan, 2011; Queiroz Neto, Lohmann, \& Scott, 2016; Wilde, Cox, Kelly, \& Harrison, 2017). The rationale underlying the new trend in destination competitiveness relied on the idea that a tourism destination should strengthen its competitive position by meeting tourists' needs more effectively than a competitor meets those needs (Pansiri, 2014). Therefore, investigation of the importance tourists give to destination competitiveness attributes became central to understanding destinations' competitive strengths.

Researchers have proposed various models to measure destination competitiveness based on different views of destination competitiveness (Crouch \& Ritchie, 1999; Hassan, 2000; Dwyer \& Kim, 2003). For instance, destination competitiveness has been defined as the "ability of a destination to provide a high standard of living for residents of the destination" (Crouch \& Ritchie, 1999, p. 137), as the "ability to create and integrate value added products that sustain resources while maintaining market 
position relative to other competitors" (Hassan, 2000, p. 240), and as the "ability of a destination to deliver goods and services that perform better than other destinations on those aspects of the tourism experience considered to be important by tourists" (Dwyer \& Kim, 2003). These destination competitiveness models were based on a suppliers' perspective (e.g., destination attributes derived from academics, managers, and the tourism industry).

However, rather than being delivered by suppliers, destination attributes are cocreated by tourists during use (Woodruff, 1997). Hence, the attributes for a successful destination should come from the demand side rather than the supply side (Crouch \& Ritchie, 1999). As incorporating a complete diversity of tourist value in one model is impossible (Dwyer \& Kim, 2003), destination competitiveness should be measured among destinations that compete in tourism niches rather than generally.

\section{The SCUBA diving tourism niche}

SCUBA diving is an activity pursued globally by millions of people (Musa \& Dimmock, 2013; O'Neill, Williams, MacCarthy, \& Groves, 2000). As a tourism experience, SCUBA diving functions as a system, in which interested and motivated divers are attracted to selected destinations to experience underwater features or attributes on offer (Dimmock \& Musa, 2015). In the 21st century, new SCUBA markets are emerging from new globally emerging economies, like China, Brazil, and Russia. Europe and North America remain important SCUBA-generating markets with a large population base that includes divers traveling to international destinations.

The profile of dive tourists covers a broad sweep of characteristics, with participation coming from all adult age groups (Garrod, 2008). Economic studies regularly show divers present in the middle- to high-income brackets, supporting capacity to finance participation (Edney, 2012; Musa, Seng, Thirumoorthi, \& Abessi, 2010; Stolk, Markwell, \& Jenkins, 2007; Thapa, Graefe, \& Meyer, 2006). In conjunction with income, diver profile research shows high educational qualifications are not unusual across the sector. For example, $75 \%$ of wreck divers in Chuuk, Micronesia, had bachelor or post-graduate qualifications, and two-thirds of artificial wreck divers in Australia reported holding tertiary qualifications (Edney, 2012; Stolk et al. 2007). A study of divers in Florida also noted high educational qualifications (Thapa et al. 2006). 
In terms of gender, male divers predominate (Stolk et al. 2007), particularly in destinations such as Malaysia (Musa et al. 2010), Australia (O'Neill et al. 2000; Stolk et al. 2007), Florida (Thapa et al. 2006), and Mozambique (Pereira \& Schleyer, 2005). However, while diving has been predominantly a male pursuit, female participation continues to grow (Edney, 2012; Worachananant, Carter, Hockings, \& Reopanichkul, 2008). Data from the Professional Association of Diving Instructors also indicate that female participation in SCUBA diving is rising (PADI, 2017).

Research on motivation to SCUBA dive has focused broadly on the chance to witness the underwater environment or the thrill of being underwater (Todd, Graefe, \& Mann, 2001). The motivation to dive in Phuket relates to underwater environments and diving skills (Dearden, Bennett, \& Rollins, 2006), while beginning divers in Florida are motivated by the thrill and challenge of diving and experienced divers are attracted by technical aspects and underwater sites (Meisel-Lusby \& Cottrell, 2008). Research in South Africa also revealed the association between motivation, diver behavior, and preferences for underwater sites (Lucrezi, Saayman, \& Merwe, 2013).

Underwater attractions can include diving on shipwrecks, exploring coral reefs, observing marine wildlife, and photography. SCUBA diving tourism can occur in all climatic zones from equatorial regions to polar sites, with the tropical zone hosting an abundance of destinations owing to the presence of tropical island locations, coral reefs, warm climate, aquatic conditions, and marine life (Lew, 2013). The range of underwater attractions available attracts divers with profiles reflecting various diving experiences and varied SCUBA qualifications.

\section{Classifying tourists through the level of travel experience}

Like people, destinations are not identical. Therefore, to develop successful marketing strategies, tourism destinations must deeply understand the characteristics of market segments (Bojanic, 1992). To gather such knowledge, researchers have investigated a number of tourists' characteristics: motivation/behavior (Dolnicar \& Fluker, 2003; Hennigs \& Hallmann, 2015; Mazanec, 1992), place in the travel life-cycle (March, 2000; Oppermann, 1995), level of specialization (Bryan, 1977; Dearden et al. 2006; Kim, Kim, \& Ritchie, 2008; Lamont \& Jenkins, 2013), and travel experience (Holden, 
1999; Li et al. 2015; Panchal \& Pearce, 2011; Paris \& Teye, 2010; Pearce \& Lee, 2005).

Level of travel experience was the basis for the development of the travel career pattern concept-formerly the travel career ladder (Pearce \& Lee, 2005) — which holds that motivation changes according to the person's travel experience and life stage. Research methodology has been criticized for not measuring an individual's travel experience through time (Ryan, 1998), as studies argue that a tourist's preferences and motivations change according to the person's level of travel experience and stage in the life cycle (Li et al. 2015; Panchal \& Pearce, 2011; Pearce \& Lee, 2005).

In measuring travel experience, studies have applied various procedures (Table 1). Among them, the number of international and domestic trips have consistently served as a measure of travel experience (Li et al. 2015; Panchal \& Pearce, 2011; Paris \& Teye, 2010; Pearce \& Lee, 2005; Sonmez \& Graefe, 1998). Additionally, the number of visited regions, countries or global regions visited, and age have been used (Paris \& Teye, 2010; Pearce \& Lee, 2005; Weaver, Weber, \& McCleary, 2007).

Table 1. Summary of studies on travel experience

\begin{tabular}{|c|c|c|c|c|}
\hline Authors & Journal/Source & Variables & $\begin{array}{l}\text { Weight or } \\
\text { Unweight }\end{array}$ & $\begin{array}{l}\text { Segmenting } \\
\text { technique }\end{array}$ \\
\hline $\begin{array}{l}\text { Oppermann } \\
\text { (1995) }\end{array}$ & $\begin{array}{l}\text { Annals } \\
\text { Tourism } \\
\text { Research }\end{array}$ & - Total number of trips & Unweighted & 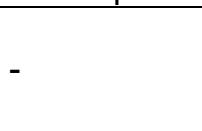 \\
\hline $\begin{array}{l}\text { Oppermann } \\
\text { (1997) }\end{array}$ & $\begin{array}{l}\text { Tourism } \\
\text { Management }\end{array}$ & $\begin{array}{ll}\text { - } & \text { First-time } \\
\text { visitor } & \text { international } \\
\text { - } & \text { Repeated international } \\
\text { visitor } & \end{array}$ & Unweighted & - \\
\hline Ryan (1998) & $\begin{array}{l}\text { Annals } \\
\text { Tourism } \\
\text { Research }\end{array}$ & $\begin{array}{l}\text { Number of times a similar } \\
\text { holiday has been taken } \\
\text { - Number of past visits }\end{array}$ & Unweighted & - \\
\hline $\begin{array}{l}\text { Sonmez and } \\
\text { Graefe (1998) }\end{array}$ & $\begin{array}{l}\text { Journal } \\
\text { Travel } \\
\text { Tesearch }\end{array}$ & $\begin{array}{ll}\text { - } & \text { Motivation for } \\
\text { international } & \text { trip } \\
\text { (business/vacations) } \\
\text { - } & \text { Last international trip } \\
\text { - } & \text { Number of international } \\
\text { trips (past five years) } \\
\text { - } \quad \begin{array}{l}\text { Number of international } \\
\text { trips (lifetime) }\end{array} \\
\text { - Number of regions visited }\end{array}$ & Unweighted & - \\
\hline $\begin{array}{l}\text { Pearce and } \\
\text { Lee (2005) }\end{array}$ & $\begin{array}{l}\text { Journal } \\
\text { Travel } \\
\text { Research }\end{array}$ & $\begin{array}{l}\text { - Number of domestic trips } \\
\text { (lifetime) } \\
\text { - Number of international } \\
\text { trips (lifetime) } \\
\text { - Age }\end{array}$ & Unweighted & $\begin{array}{l}\text { K-means } \\
\text { cluster } \\
\text { analysis }\end{array}$ \\
\hline
\end{tabular}




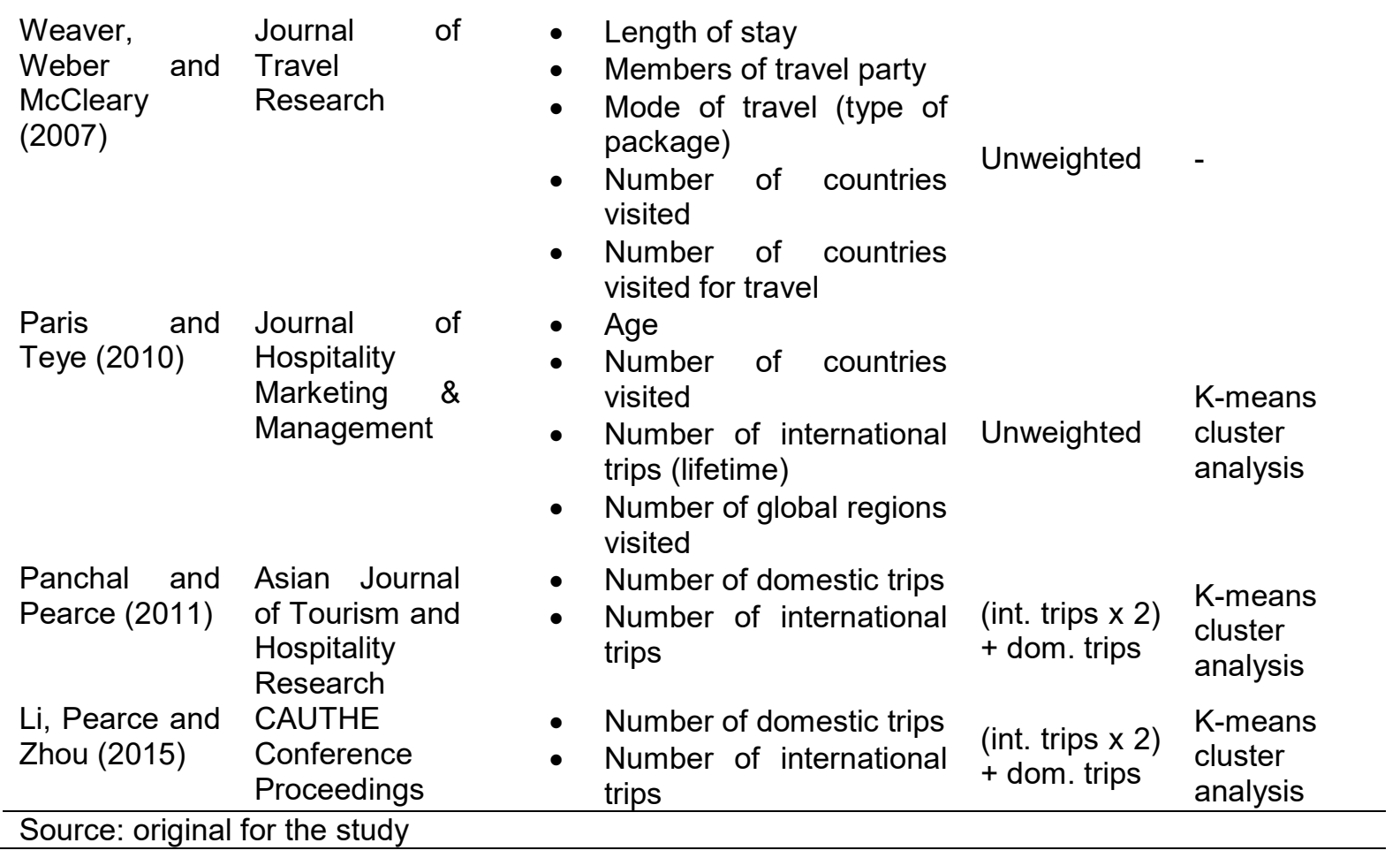

Previous studies have not explored in depth the idea that different variables have different weights on the final score of a travel experience level. Fundamentally, travel experience has often been measured without giving weight to variables, except for recent work on the travel career pattern (Li et al. 2015; Panchal \& Pearce, 2011). In these two cases, the score for international experience was doubled as the authors argued that overseas experiences were powerful contributors to the construction of travel experience level (Li et al. 2015; Panchal \& Pearce, 2011; Pearce \& Lee, 2005).

Overall, the classification of tourists according to their level of travel experience has been applied mainly in studies on tourism motivations (Chen, Bao, \& Huang, 2014; Huang \& Hsu, 2009; Oh, Assaf, \& Baloglu, 2014; Paris \& Teye, 2010; Pearce \& Lee, 2005; Weaver et al. 2007). In light of this limited use, the application of the travel experience approach in a new area (destination competitiveness) contributes to a better understanding of tourists' preferences, particularly in the case of SCUBA diving tourism.

\section{Methodology}

Our study investigated the extent to which level of travel experience influenced the importance SCUBA diving tourists give to destination competitiveness attributes of a 
hypothetical successful SCUBA diving destination. To achieve this aim, we developed and administered an online survey. The questionnaire comprised 19 questions covering four areas-demographic aspects, travel experience, travel preference, and SCUBA diving experience-and also included assessment of 52 attributes of destination competitiveness. The questionnaire was based on the literature (Pearce \& Lee, 2005; Panchal \& Pearce, 2011) and on interviews with SCUBA diving tourists in four popular SCUBA diving destinations in Thailand and Australia.

We followed a convenience sample approach to our research (Bryman \& Bell, 2011). Eligible respondents were certified SCUBA divers over 18 years of age who had travelled to domestic or international SCUBA diving destinations. Our multi-faceted strategy for recruiting respondents included a website to publicize the research, paid advertisements on Facebook groups, and direct emails to SCUBA diving operators at popular SCUBA diving destinations (Australia, Thailand, Indonesia, Egypt, Mexico, Malaysia, USA). The survey was available online from January to June 2016 and resulted in a total of 712 fully completed questionnaires (120 incomplete questionnaires were discarded).

Once the survey closed, we began data analysis, relying on several approaches: descriptive analysis, principal components analysis, k-means cluster analysis, crosstabulation, and analysis of variance (ANOVA) with the least significant difference post hoc comparison. We employed descriptive analysis (Alreck \& Settle, 1995) to describe the basic features of the data, such as demographic characteristics, travel characteristics, and the importance of various destination competitiveness attributes. We used principal components analysis to discover common underlying factors in the set of 52 destination competitiveness variables (Dwyer, Mellor, Livaic, Edwards, \& $\mathrm{Kim}, 2004)$. We relied on k-means cluster analysis to classify respondents according to their level of travel experience, as implemented in previous studies (Li et al. 2015; Panchal and Pearce, 2011). We used cross-tabulation to scrutinize respondents' profiles according to respondents' level of travel experience. Finally, we applied analysis of variance to examine the difference in the identified destination competitiveness factors (a group of correlated destination competitiveness attributes) among travel experience groups. We employed IBM SPSS 23 to analyse the data. 


\section{Results}

\section{Profile of respondents and travel characteristics}

Table 2 summarizes the sample profile in terms of gender, age, level of education, and country of residence. As previous studies of SCUBA divers have found (Dearden et al. 2006; Edney, 2012; Garrod, 2008), the majority of respondents are male (61\%), and the largest age ranges were 36-45 (24\%), 46-55 (27\%), and-perhaps surprisingly-over 55 (23.2\%). Regarding education, the majority of respondents $(72 \%)$ indicated holding at least a university degree and among them, $45 \%$ hold postgraduate qualifications. Respondents were primarily from Australia (25\%), North America (23\%), and the United Kingdom (13\%).

Table 2. Profile of respondents $(n=712)$.

\begin{tabular}{lll}
\hline Attribute & Frequency & $\mathbf{( \% )}$ \\
\hline Gender & & \\
Male & 432 & $(61.4)$ \\
Female & 272 & $(38.6)$ \\
& & \\
Age groups & 58 & \\
18-25 years old & 122 & $(8.1)$ \\
26-35 years old & 172 & $(17.1)$ \\
$36-45$ years old & 195 & $(24.2)$ \\
46-55 years old & 165 & $(27.4)$ \\
More than 55 years old & & \\
& & \\
Highest level of education & 57 & $(8.1)$ \\
High-School & 139 & $(19.7)$ \\
Technical/trade Qualification & 283 & $(40.0)$ \\
University degree & 228 & $(32.2)$ \\
Postgraduate degree & & \\
& 181 & $(25.4)$ \\
Country of residence & 161 & $(22.6)$ \\
Australia & 95 & $(13.3)$ \\
The United States of America & United Kingdom & $(7.4)$ \\
France & & $(6.0)$ \\
Brazil & & $(3.4)$ \\
Canada & & $(21.8)$ \\
Others & 24 & \\
\hline
\end{tabular}

The travel characteristics section of the questionnaire was based on previous studies (Li et al. 2015; Panchal \& Pearce, 2011; Paris \& Teye, 2010) (Table 3). In addition to the total number of domestic and international trips, two other variables were included: 
domestic and international trips specifically to SCUBA diving destinations. The purpose of inclusion was to investigate respondents' travel characteristics within the particular SCUBA diving tourism niche. Responses show that with respect to overall international and domestic leisure trips, respondents were highly experienced, with $70 \%$ having made more than 10 international trips and $83 \%$ more than ten domestic trips. With respect to specifically SCUBA diving trips, respondents were also highly experienced and engaged both domestically ( $26 \%$ had made more than 25 trips) and internationally ( $43 \%$ had made more than ten trips). Respondents usually travelled with partners $(37 \%)$ or friends $(31 \%)$ and within the same global region $(32 \%)$. Two respondents noted that on top of the five global regions, they had also visited Antarctica.

Table 3. Travel characteristics

\begin{tabular}{|c|c|c|}
\hline Attribute & Frequency & (\%) \\
\hline \multicolumn{3}{|c|}{ Number of international leisure trips } \\
\hline 0 & 20 & (2.8) \\
\hline $1-4$ & 75 & $(10.7)$ \\
\hline $5-10$ & 114 & (16.0) \\
\hline More than 10 & 503 & (70.5) \\
\hline \multicolumn{3}{|c|}{ Number of international SCUBA diving trips } \\
\hline 0 & 53 & (7.4) \\
\hline $1-4$ & 195 & (27.4) \\
\hline $5-10$ & 155 & (21.8) \\
\hline More than 10 & 309 & $(43.4)$ \\
\hline \multicolumn{3}{|c|}{ Number of domestic leisure trips ( +3 days) } \\
\hline 0 & 22 & (3.1) \\
\hline $1-4$ & 48 & (6.7) \\
\hline $5-10$ & 49 & (6.9) \\
\hline $10-25$ & 141 & (19.8) \\
\hline More than 25 & 452 & $(63.4)$ \\
\hline \multicolumn{3}{|c|}{ Number of domestic SCUBA diving trips (+3 days) } \\
\hline 0 & 66 & $(9.3)$ \\
\hline $1-4$ & 165 & (23.2) \\
\hline $5-10$ & 109 & (15.3) \\
\hline $10-25$ & 184 & (25.8) \\
\hline More than 25 & 188 & $(26.4)$ \\
\hline \multicolumn{3}{|c|}{ Number of global regions visited } \\
\hline One region & 227 & (31.9) \\
\hline Two regions & 182 & $(25.6)$ \\
\hline Three regions & 170 & (23.9) \\
\hline Four regions & 100 & (14.0) \\
\hline Five regions & 31 & $(4.4)$ \\
\hline 5 regions + Antarctica & 2 & $(0.3)$ \\
\hline
\end{tabular}

Travel party 


\begin{tabular}{lll} 
Alone & 158 & $(22.2)$ \\
With partner & 261 & $(36.7)$ \\
With partner and kids & 47 & $(6.6)$ \\
With friends & 220 & $(30.9)$ \\
Other & 26 & $(3.7)$ \\
\hline
\end{tabular}

\section{Importance of destination competitiveness factors}

The importance of the 52 destination attributes was measured through a seven-point Likert-type scale $(1=$ not important at all, $4=$ neutral, $7-=$ very important). We employed factor analysis to discover underlying factors in the set of variables and to reduce the data (Dwyer et al. 2004) and to identify groups of correlated destination attributes. Principal components analysis was used with Varimax rotation. Through consideration of eigenvalues greater than 1 , ten factors emerged. Variables with factor loadings of less than 0.50 were disregarded and the total amount of variance explained was $67.26 \%$. Table 4 shows the importance of each destination competitiveness attribute and factor.

Table 4. Destination competitiveness attributes and factors - Ranked by eigenvalue

\begin{tabular}{|c|c|c|c|c|c|}
\hline Factor & Loading & Mean & Eigenvalue & $\begin{array}{c}\text { (\%) of } \\
\text { variance } \\
\text { explaine } \\
\text { d }\end{array}$ & $\begin{array}{c}\text { Cronbach } \\
\text { alpha }\end{array}$ \\
\hline Diving operations & & 5.95 & 3.295 & $(-8.04)$ & 0.792 \\
\hline Professional operations & 0.775 & 6.38 & & & \\
\hline Environmental commitment of the dive operator & 0.728 & 6.09 & & & \\
\hline Friendly staff/Casual atmosphere & 0.664 & 6.09 & & & \\
\hline Information by the dive master/Dive briefing & 0.539 & 5.28 & & & \\
\hline Risk perception & & 5.44 & 3.049 & $(-7.44)$ & 0.917 \\
\hline Lack of disease outbreaks & 0.886 & 5.55 & & & \\
\hline Lack of terrorism threat & 0.839 & 5.42 & & & \\
\hline Political stability & 0.826 & 5.32 & & & \\
\hline Diving conditions & & 5.42 & 2.557 & $(-6.24)$ & 0.749 \\
\hline Variety and abundance of marine life & 0.769 & 6.25 & & & \\
\hline Quality and environmental conditions of the dive site & 0.716 & 6.15 & & & \\
\hline Good underwater visibility & 0.702 & 5.97 & & & \\
\hline Warm water & 0.574 & 4.56 & & & \\
\hline Easy dive conditions & 0.548 & 4.16 & & & \\
\hline Destination management & & 5.05 & 3.332 & $(-8.13)$ & 0.865 \\
\hline Hygiene, cleanliness and sanitation & 0.664 & 5.97 & & & \\
\hline
\end{tabular}


Security and visitors' safety

$0.643 \quad 5.97$

Health and medical facilities

$0.63 \quad 5.53$

$\begin{array}{lll}\text { Easy access to tourist information online } & 0.59 & 4.66\end{array}$

$\begin{array}{lll}\text { Easy access to tourist information on-site } & 0.531 & 4.49\end{array}$

Local transport quality

$0.528 \quad 4.42$

Destination airport quality

$0.507 \quad 4.29$

Price

5.13

Price of SCUBA diving services

$0.787 \quad 5.33$

3.262

$(-7.96)$

0.827

Price of accommodation services

0.786

5.31

Price of transport to the destination

$0.686 \quad 5.24$

Price of restaurant services

0.666

4.67

Big wildlife encounters

Opportunity to dive with manta rays

4.85

0.879

4.99

Opportunity to dive with whales

0.858

4.89

Opportunity to dive with sharks

0.832

4.68

\section{Diving training}

4.29

Good dive master/Dive guide

5.43

Opportunity to improve diving skill/ diving training

package

Rental equipment available

General tourist attractions

4.07

Natural scenery/ landscape

$\begin{array}{ll} & \mathbf{4 . 0 7} \\ 0.744 & 5.10\end{array}$

$0.734 \quad 4.52$

Local lifestyle

4.52
4.29

Historical and cultural activities

3.47

Adventure activities

0.704

2.98

Entertainment activities and facilities

0.603

Technical diving

$0.771 \quad 4.14$

Opportunity to do a deep dive (below 30 meters)

0.690

3.50

Opportunity to dive in a cave

3.65

0.783

3.71

Cost of visa

0.772

3.59

No visa required

Ranked according to their level of importance, the ten destination competitiveness factors were labeled as (1) diving operations, (2) risk perception, (3) diving conditions, (4) destination management, (5) price, (6) big wildlife encounters, (7) diving training,

(8) general tourist attractions, (9) tech diving, and (10) visa policy. 
To classify respondents according to their level of travel experience, we used a computation of two variables to determine the travel experience score for each respondent: number of international trips and number of domestic trips. The standardized number ( $Z$ score) of international trips was doubled and then summed with the standardized number of domestic trips (Li et al. 2015; Panchal \& Pearce, 2011; Pearce \& Lee, 2005). Owing to the sample size (>200 cases), we then employed a k-means cluster analysis to classify groups according to respondent's level of experience. After six iterations, three travel experience groups emerged with cluster centers of $-4.65,-0.38$ and 1.82 and were labeled as low (16.9\%), medium (33.3\%), and high travel experience (49.9\%) (Table 5). Results showed the majority of the SCUBA diving tourists in this sample are highly experienced tourists.

Table 5. Groups according to level of travel experience

\begin{tabular}{llll}
\hline Attributes & $\begin{array}{l}\text { Low } \\
\text { travel experience }\end{array}$ & $\begin{array}{l}\text { Medium } \\
\text { travel experience }\end{array}$ & $\begin{array}{l}\text { High } \\
\text { travel experience }\end{array}$ \\
\hline N. of cases $(\%)$ & $120(16.9 \%)$ & $237(33.3 \%)$ & $355(49.9 \%)$ \\
Final cluster centers & -4.65 & -0.38 & 1.82 \\
\hline
\end{tabular}

To determine the profile of the three travel experience groups, we used a crosstabulation analysis (Table 6). An analysis of variance (ANOVA) was employed to determine whether the three groups differed significantly in terms of demographic and travel characteristics. The result was significant $(p=.001)$ for age groups, highest level of education, international trips, international SCUBA diving trips, domestic trips, domestic SCUBA diving trips, and global regions visited. The low travel experience group was on average 36 years of age, with the majority holding a trade qualification $(32 \%)$ and university degree (36\%). Further, the majority had undertaken between one and four international trips (63\%), between one and four international SCUBA diving trips (61\%), more than 25 domestic trips (32\%), and between ten and 25 domestic SCUBA diving trips (23\%), and had travelled mainly in their own global region (73\%). The medium travel experience group was 43 years of age on average, with the majority having university (37\%) and post-grad degrees (33\%). This group had taken more than five international trips (100\%), one to four international SCUBA diving trips (30\%), more than ten domestic trips (75\%), and between five and 25 domestic SCUBA diving trips (49\%), and had visited two global regions (31\%). Lastly, at an average age of 48 , the high travel experience group was older, with the majority of respondents 
having university (43\%) and post-grad degrees (35\%). Respondents in this group had made more than ten international trips $(100 \%)$, more than ten international SCUBA diving trips $(63 \%)$, more than 25 domestic trips $(100 \%)$, and more than 25 domestic SCUBA diving trips (39\%), and had visited more than three global regions (54\%).

Table 6. Cross-tabulation profile $\mathrm{x}$ travel experience level groups

\begin{tabular}{|c|c|c|c|c|c|c|c|}
\hline Profile & Categories & Low & $(\%)$ & Medium & $(\%)$ & High & $(\%)$ \\
\hline \multirow[t]{2}{*}{ Gender } & Male & 77 & (64.2) & 135 & (57.7) & 220 & (62.9) \\
\hline & Female & 43 & (35.8) & 99 & $(42.3)$ & 130 & (37.1) \\
\hline \multirow[t]{5}{*}{ Age groups* } & $18-25$ years old & 20 & $(16.7)$ & 21 & (8.9) & 17 & $(4.8)$ \\
\hline & $26-35$ years old & 36 & (30) & 45 & $(19)$ & 41 & $(11.5)$ \\
\hline & $36-45$ years old & 32 & (26.7) & 61 & (25.7) & 79 & (22.3) \\
\hline & $46-55$ years old & 21 & (17.5) & 62 & (26.2) & 112 & (31.5) \\
\hline & More than 55 years old & 11 & $(9.2)$ & 48 & (20.3) & 106 & (29.9) \\
\hline \multirow{4}{*}{$\begin{array}{l}\text { Highest level of } \\
\text { education* }\end{array}$} & High-School & 12 & $(10)$ & 21 & (8.9) & 24 & $(6.8)$ \\
\hline & Technical/Trade Qualification & 38 & $(31.7)$ & 50 & $(21.2)$ & 51 & (14.5) \\
\hline & University Degree & 43 & (35.8) & 88 & (37.3) & 152 & (43.3) \\
\hline & Post-Grad Degree & 27 & (22.5) & 77 & $(32.6)$ & 124 & (35.3) \\
\hline \multirow{7}{*}{$\begin{array}{l}\text { Country } \\
\text { residency }\end{array}$} & Australia & 42 & (35) & 65 & $(27.4)$ & 74 & $(20.8)$ \\
\hline & Brazil & 17 & $(14.2)$ & 9 & $(3.8)$ & 17 & $(4.8)$ \\
\hline & United Kingdom & 2 & $(1.7)^{\prime}$ & 21 & (8.9) & 72 & $(20.3)$ \\
\hline & France & 7 & (5.8) & 21 & (8.9) & 25 & (7) \\
\hline & United States of America & 23 & $(19.2)$ & 54 & (22.8) & 84 & $(23.7)$ \\
\hline & Canada & 4 & $(3.3)^{\prime}$ & 9 & $(3.8)^{\prime}$ & 11 & $(3.1)^{\prime}$ \\
\hline & Others & 25 & $(20.8)$ & 58 & $(24.5)$ & 72 & (20.3) \\
\hline \multirow{4}{*}{$\begin{array}{l}\text { International } \\
\text { trips* }\end{array}$} & 0 & 19 & $(15.8)$ & 0 & $(0)$ & 0 & (0) \\
\hline & $1-4$ & 76 & (63.3) & 0 & (0) & 0 & (0) \\
\hline & $5-10$ & 24 & (20) & 90 & (38) & 0 & (0) \\
\hline & More than 10 & 1 & $(0.8)$ & 147 & (62) & 355 & $(100)$ \\
\hline International & 0 & 36 & $(30)$ & 13 & $(5.5)$ & 4 & $(1.1)$ \\
\hline \multirow[t]{3}{*}{ SCUBA trips* } & $1-4$ & 73 & (60.8) & 72 & $(30.4)$ & 49 & (13.8) \\
\hline & $5-10$ & 10 & $(8.3)^{\prime}$ & 69 & (29.1) & 77 & (21.7) \\
\hline & More than 10 & 1 & $(0.8)$ & 83 & (35) & 225 & (63.4) \\
\hline \multirow[t]{5}{*}{ Domestic trips* } & 0 & 10 & (8.3) & 5 & $(2.1)$ & 0 & (0) \\
\hline & $1-4$ & 30 & $(25)^{\prime}$ & 25 & (10.5) & 0 & (0) \\
\hline & $5-9$ & 20 & (16.7) & 29 & (12.2) & 0 & (0) \\
\hline & $10-25$ & 22 & (18.3) & 119 & (50.2) & 0 & (0) \\
\hline & More than 25 & 38 & (31.7) & 59 & $(24.9)$ & 355 & (100) \\
\hline \multirow{5}{*}{$\begin{array}{l}\text { Domestic } \\
\text { SCUBA trips* }\end{array}$} & 0 & 7 & $(5.8)$ & 21 & (8.9) & 33 & $(9.3)$ \\
\hline & $1-4$ & 48 & $(40)^{\prime}$ & 67 & (28.3) & 52 & (14.6) \\
\hline & $5-10$ & 19 & (15.8) & 54 & (22.8) & 39 & (11) \\
\hline & $10-25$ & 28 & (23.3) & 63 & (26.6) & 93 & $(26.2)$ \\
\hline & More than 25 & 18 & (15) & 32 & (13.5) & 138 & (38.9) \\
\hline \multirow{4}{*}{$\begin{array}{l}\text { Global regions } \\
\text { visited }^{*}\end{array}$} & One region & 87 & (72.5) & 65 & $(27.4)$ & 75 & (21.1) \\
\hline & Two regions & 20 & (16.7) & 74 & (31.2) & 88 & (24.8) \\
\hline & Three regions & 10 & $(8.3)$ & 64 & $(27)$ & 96 & (27) \\
\hline & Four regions & 2 & $(1.7)$ & 27 & (11.4) & 71 & (20) \\
\hline
\end{tabular}




\begin{tabular}{llllllll} 
& Five regions & 1 & $(0.8)$ & 7 & $(3)$ & 23 & $(6.5)$ \\
& 5 regions + Antarctica & 0 & $(0)$ & 0 & $(0)$ & 2 & $(0.6)$ \\
Travel party & & & & & & \\
& & 25 & $(20.8)$ & 47 & $(19.8)$ & 86 & $(24.2)$ \\
& By yourself & 46 & $(38.3)$ & 86 & $(36.3)$ & 129 & $(36.3)$ \\
& With partner & 7 & $(5.8)$ & 18 & $(7.6)$ & 22 & $(6.2)$ \\
& With partner and kids & 38 & $(31.7)$ & 80 & $(33.8)$ & 102 & $(28.7)$ \\
& With friends & 4 & $(3.3)$ & 6 & $(2.5)$ & 16 & $(4.5)$ \\
\hline & Others & & & & & & \\
\hline${ }^{*} \mathrm{p}<0.001$ & & & & & &
\end{tabular}

\section{Importance of destination competitiveness factors and travel experience levels}

To identify the extent to which level of travel experience influences the importance respondents place on destination competitiveness factors for a successful SCUBA diving destination, we used analysis of variance (ANOVA). The dependent variables comprised the ten destination competitiveness factors and the independent variables were the travel experience levels. The results appear in Table 7.

Table 7. ANOVA: Destination competitiveness factors by travel experience groups

\begin{tabular}{|c|c|c|c|c|c|c|c|c|c|}
\hline \multirow[b]{2}{*}{ DC Factors } & \multicolumn{3}{|c|}{$\begin{array}{l}\text { Mean by level of travel } \\
\text { experience }\end{array}$} & \multirow[b]{2}{*}{$\mathrm{F}$} & \multirow[b]{2}{*}{ df } & \multirow[b]{2}{*}{ Sig } & \multicolumn{2}{|c|}{$\begin{array}{l}\text { Post - } \\
\text { comparison }\end{array}$} & \multirow{2}{*}{$\begin{array}{l}\mathrm{Hoc} \\
\mathrm{M}-\mathrm{H}\end{array}$} \\
\hline & Low & Medium & High & & & & L-M & $\mathrm{L}-\mathrm{H}$ & \\
\hline Diving Operations & 6.0756 & 6.0533 & 5.8437 & 3.795 & 2.705 & 0.02 & & * & * \\
\hline Risk Perception & 5.8333 & 5.4674 & 5.2861 & 5.874 & 2.699 & 0.00 & * & * & \\
\hline Diving Conditions & 5.4353 & 5.4730 & 5.3713 & 0.746 & 2.708 & 0.48 & & & \\
\hline Destination Management & 5.3141 & 5.1297 & 4.9005 & 7.605 & 2.708 & 0.00 & & * & * \\
\hline Price & 5.2521 & 5.2700 & 5.0054 & 5.481 & 2.708 & 0.00 & & * & * \\
\hline Diving Training and service & 5.0294 & 4.4754 & 3.9066 & 29.023 & 2.708 & 0.00 & * & * & * \\
\hline Big Wildlife Encounters & 4.9398 & 4.8664 & 4.8174 & 0.33 & 2.708 & 0.72 & & & \\
\hline General Tourist Attractions & 4.4303 & 4.0743 & 3.9463 & 6.496 & 2.708 & 0.00 & * & * & * \\
\hline Visa Policy & 4.3992 & 3.7288 & 3.3484 & 18.617 & 2.705 & 0.00 & * & * & * \\
\hline Technical Diving & 4.2619 & 3.9641 & 4.1563 & 2.003 & 2.708 & 0.14 & & & \\
\hline
\end{tabular}

Overall, among the three groups we found statistical significance in seven of the ten destination competitiveness factors (Figure 1): diving operations, risk perception, destination management, price, diving training and service, general tourist attractions and visa policy (colourful marks in Figure 1). We found no significance for diving 
conditions, big wildlife encounters, and tech diving factors (blank marks in Figure 1). All significant factors presented the same trend: the higher the travel experience, the lower the importance of the destination competitiveness factor. The results were diving operations $(6.07,6.05$, and 5.84$)$, risk perception $(5.83,5.47$, and 5.29$)$, destination management $(5.31,5.13$, and 4.90$)$, diving training and service $(5.03,4.48$, and 3.90$)$, general tourist attractions $(4.43,4.07$, and 3.94$)$ and visa policy $(4.40,3.73$, and 3.35$)$. This trend suggests evidence of a career pattern reflecting the importance given to destination competitiveness factors.

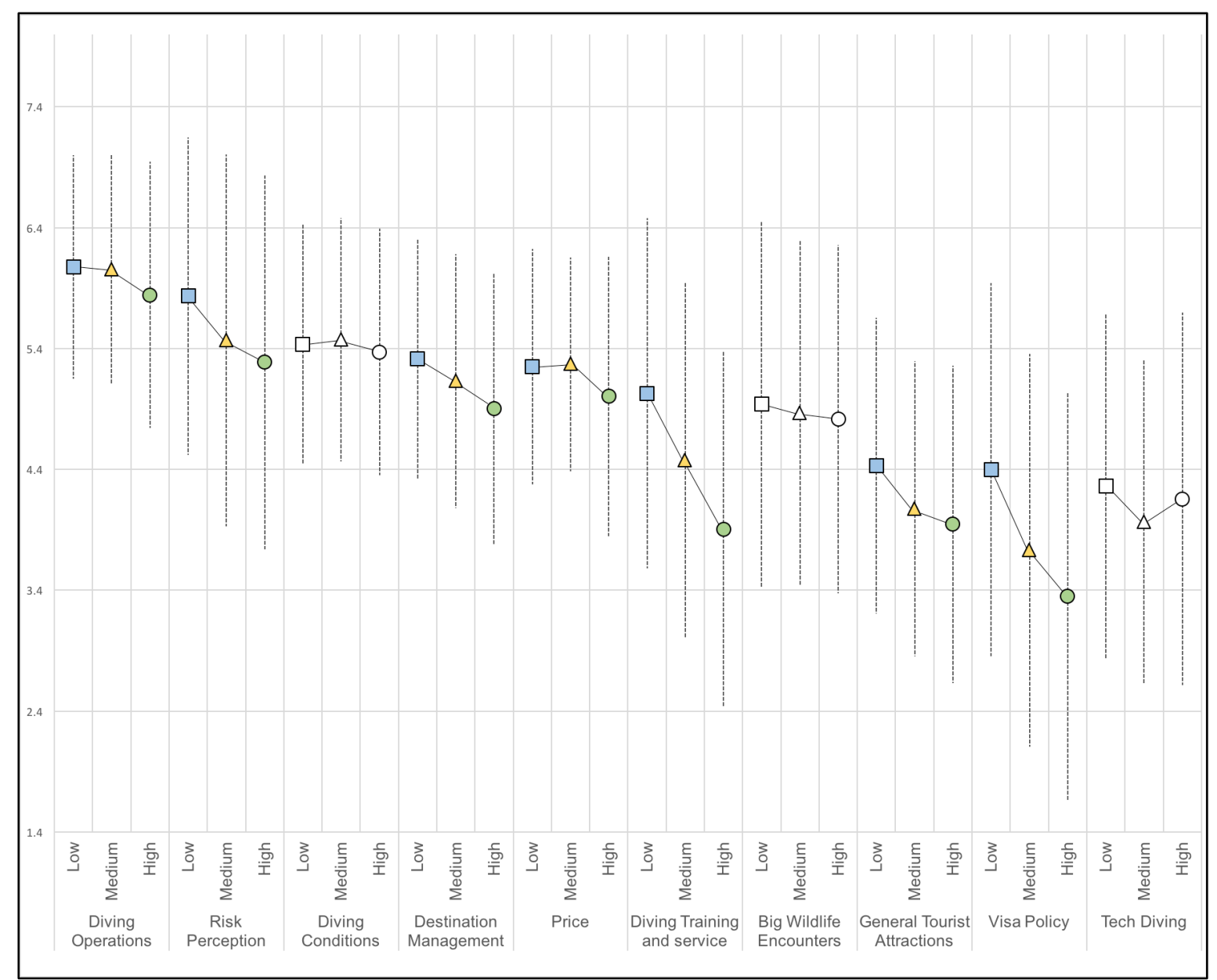

Figure 1. Mean scores for destination competitiveness factors across different travel experience groups 
The importance each travel group experience level gave to destination factors was ranked to identify the important and unimportant factors across different levels of travel experience (Figure 2). Diving operations (1) and general tourist attractions (8) did not change positions, and were respectively of high importance and low importance for all groups of travel experience. Risk perception, the second most important factor for the low travel experience group, decreased its importance (third for medium and high travel experience groups). Diving conditions, the third most important factor for the low travel experience group, increased its importance (second for medium and high travel experience groups). Destination management, the fourth most important factor for the low travel experience group, decreased its importance (fifth for medium and high travel experience groups). Price, $5^{\circ}$ most important factor for the low travel experience group, increased its importance ( $4^{\circ}$ for medium and high travel experience groups). Diving training and service, sixth most important factor for the low travel experience group, dropped its importance twice: seventh for the medium and ninth for the high travel experience group. Big wildlife encounters, seventh most important factor for low travel experience group, increased its importance (sixth for the medium and high travel experience groups). Visa policy, ninth most important factor for low travel experience group, became the least important factor (tenth) for the medium and high travel experience groups. Finally, tech diving, the least important factor (tenth) for the low travel experience group, increased its importance in both groups: ninth most important for the medium and seventh most important for the high travel experience group.

As these results show, two groups of factors changed across all travel experience levels: diving training and service and tech diving. Both factors comprise destination attributes specifically related to diving activities. Further, they showed a relationship with a respondent's diving experience: diving training and services are 
related to novice divers and tech diving to high experience divers. As Table 6 shows, members of the high travel experience group were also experienced in diving travel characteristics, reinforcing the changes in importance given to these factors.

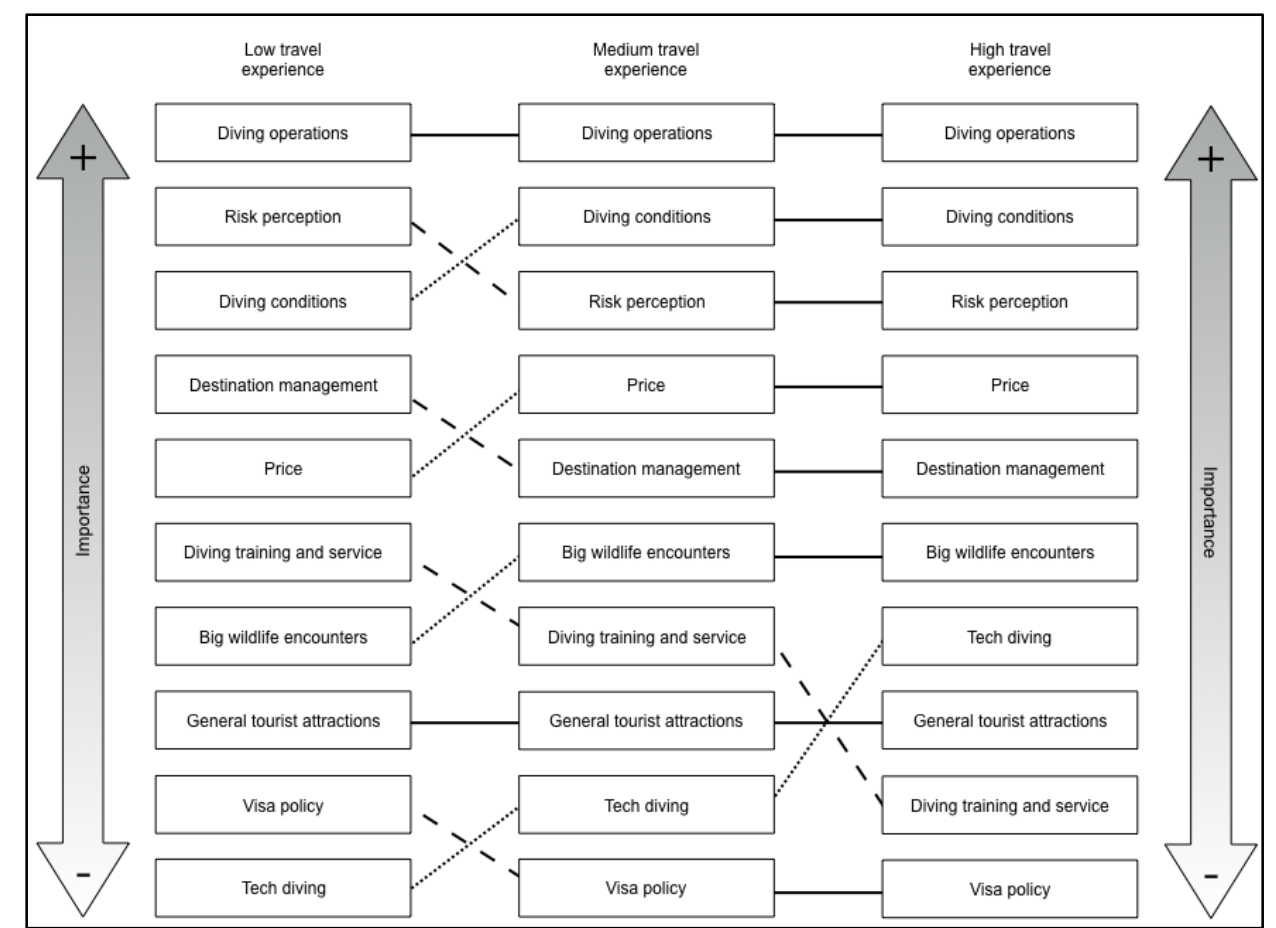

Figure 2. Ranking of the importance of destination competitiveness factors across travel experience level groups

\section{Findings and conclusions}

This study set out to investigate the extent to which the level of travel experience influences the importance SCUBA diving tourists give to destination competitiveness factors for a successful SCUBA diving destination. In contrast to the focus of previous research on socioeconomic prosperity or quality of life of residents (Crouch \& Ritchie, 1999; Dwyer \& Kim, 2003; Knežević Cvelbar, Dwyer, Koman, \& Mihalič, 2016), the study followed the rationale that a destination should strengthen its competitive position by surpassing competitors in meeting tourists' needs (Pansiri, 2014). To our knowledge, this study is the first attempt to examine the importance of destination competitiveness attributes to tourists with different levels of travel experience.

The results showed the importance of destination competitiveness factors changed across groups of SCUBA diving tourists with different levels of travel experience. 
Statistical significance was found in seven out of ten destination competitiveness factors: diving operations, risk perception, destination management, price, diving training and service, general tourist attraction and visa policy. No significance was found with diving conditions, big wildlife encounters, and tech diving. The results disclosed that the ranking of the importance of destination competitiveness factors differed with respondents' level of travel experience.

Three groups of travel experience emerged from the SCUBA diving tourists who participated in the research. The measurement of travel experience using a computation of international and domestic trips was adequate, with the potential for other variables to be used in the future (e.g., the number of global regions visited). Although an increased number of international trips provides tourists with more experience (Pearce \& Lee, 2005), tourists who travelled to different global regions may actually have more experience than those who travel in their own global region. For example, a European who travelled to six countries in three global regions may be more experienced than a European who travelled to eight European countries. Future research might investigate the weight of these variables in measuring travel experience.

Although the methodological approach might be improved, our use of travel experience was appropriate. This study demonstrated that travel experience was a suitable method for classifying tourists not only in terms of travel motives but also regarding preferred destination attributes. Therefore, future studies should consider the application of travel experience classification to identify tourists' perspectives regarding different sets of variables, such as satisfaction, happiness, and preferences in general.

The key implication for the management of SCUBA diving destinations is that destinations are more or less competitive according to the level of travel experience. Considering that destination attributes are constituted by the availability of resources (e.g. diving conditions and big wildlife encounters) and the way these resources are managed (e.g. diving operations, diving training and destination management), it is imperative that stakeholders recognise its strengths and weakness to develop an appropriate marketing strategy for the each sub-niche (low to high travel experience). For instance, SCUBA diving destinations with easy diving conditions, abundance of big marine wildlife and tech diving opportunities would be naturally more competitive 
in high than low travel experienced sub-niche. At the same time, SCUBA diving destinations could focus on aspects that are more relevant to the low experienced subniche, such as risk and destination management; and, diving training and services.

Overall, the study's results support the dynamism of destination competitiveness from the demand perspective, not only in a niche sector (SCUBA diving tourism) but also in sectors within a niche (sub-niches according to the level of travel experience). Therefore, to improve the market position (Hassan, 2000), destination competitiveness should be measured among destinations that compete in the same niche while taking sub-niches into consideration. Future destination competitiveness studies should consider four issues: (1) improvement of the theoretical discussion on the goals of destination competitiveness studies (Knežević Cvelbar et al. 2016), (2) investigation of different destination attributes according to different tourism market niches and sub-niches (e.g. dark tourism, birdwatching tourism, cruise tourism, wine tourism), (3) investigate the importance of destination attributes of this study through the perspective of the supply side, and (4) use of the set of destination attributes of this study to empirically compare and rank SCUBA diving destinations across different types of tourists.

Like all research, our study has limitations. The findings must be interpreted in the context of SCUBA diving tourism and cannot be generalized. This study considered only certified SCUBA divers in the sample, and disregarded other customers that undertake SCUBA diving activities, such as tourists who were trial divers or were under SCUBA training (another opportunity for further research). For instance, destination attributes that were excluded in this study (due to the factor loading of less than 0.5) might have a different importance within different scuba diving segments. Finally, the online survey also suffered from some limitations, such as the inability to reach SCUBA divers who do not have access to the internet, the absence of an interviewer to further explain a question to the respondent, and respondents who lacked the willingness to answer the questionnaire properly.

\section{References}

Alreck, P. L., \& Settle, R. B. (1995). The survey research handbook. Salisbuty: Irwin. 
Andrades-Caldito, L., Sánchez-Rivero, M., \& Pulido-Fernández, J. I. (2014). Tourism destination competitiveness from a demand point of view: an empirical analysis for Andalusia. Tourism Analysis, 19(4), 425-440. doi:10.3727/108354214X14090817031035

Bojanic, D. C. (1992). A look at modernized family life cycle and overseas travel. Journal of Travel \& Tourism Marketing, 1(1), 61-79. doi:10.1300/J073v01n01_05

Bryan, H. (1977). Leisure value systems and recreational specialization: The case of trout fishermen. Journal of Leisure Research, 9, 174-187.

Bryman, A., \& Bell, E. (2011). Business research methods. Oxford: Oxford University Press.

Chen, G., Bao, J., \& Huang, S. (2014). Segmenting Chinese Backpackers by Travel Motivations. International Journal of Tourism Research, 16(4), 355-367. doi:10.1002/jtr.1928

Crouch, G. I., \& Ritchie, J. R. B. (1999). Tourism, competitiveness, and societal prosperity. Journal of Business Research, 44, 137-152.

D'Hauteserre, A.-M. (2000). Lessons in managed destination competitiveness: the case of Foxwoods Casino Resort. Tourism Management, 21(1), 23-32. doi: 10.1016/S0261-5177(99)00097-7

Dearden, P., Bennett, M., \& Rollins, R. (2006). Implications for coral reef conservation of diver specialization. Environmental Conservation, 33(4), 353-363.

Dimmock, K., \& Musa, G. (2015). SCUBA Diving Tourism System: a framework for collaborative management and sustainability. Marine Policy, 54(0), 52-58. doi: 10.1016/j.marpol.2014.12.008

Dolnicar, S., \& Fluker, M. (2003). Behavioural market segments among surf tourists: investigating past destination choice. The journal of sport tourism, 8(3), 186196.

Dwyer, L., Forsyth, P., \& Rao, P. (2000). The price competitiveness of travel and tourism: a comparison of 19 destinations. Tourism Management, 21(1), 9-22. doi: 10.1016/S0261-5177(99)00081-3

Dwyer, L., \& Kim, C. (2003). Destination competitiveness: determinants and indicators. Current Issues in Tourism, 6(5), 369-414.

Dwyer, L., Mellor, R., Livaic, Z., Edwards, D., \& Kim, C. (2004). Attributes of destination competitiveness: a factor analysis. Tourism Analysis, 9(1-1), 91101. doi:10.3727/1083542041437558

Edney, J. (2012). Diver characteristics, motivations, and attitudes: Chuuk Lagoon. Tourism in Marine Environments, 8(1/2), 7-18.

Enright, M. J., \& Newton, J. (2004). Tourism destination competitiveness: a quantitative approach. Tourism Management, 25(6), 777-788. doi: 10.1016/j.tourman.2004.06.008

Eysenbach, G. (2004). Improving the Quality of Web Surveys: The Checklist for Reporting Results of Internet E-Surveys (CHERRIES). Journal of Medical Internet Research, 6(3). 
Garrod, B. (2008). Market segments and tourist typologies for diving tourism. In B. Garrod \& S. Gössling (Eds.), New frontiers in marine tourism: diving experiences, sustainability, management. Amsterdam: Elsevier.

Gooroochurn, N., \& Sugiyarto, G. (2005). Competitiveness indicators in the travel and tourism industry. Tourism Economics, 11(1), 25-43. doi: $10.5367 / 0000000053297130$

Hassan, S. S. (2000). Determinants of market competitiveness in an environmentally sustainable tourism industry. Journal of Travel Research, 38, 239-245.

Heath, E. (2003). Towards a model to enhance destination competitiveness: a southern African perspective. Journal of Hospitality \& Tourism Management, 10(2), 124-141.

Hennigs, B., \& Hallmann, K. (2015). A motivation-based segmentation study of kitesurfers and windsurfers. Managing Sport and Leisure, 20(2), 117-134. doi:10.1080/13606719.2014.979554

Holden, A. (1999). Understanding skiers motivation using Pearces travel career construct. Annals of Tourism Research, 26(2), 435-438. doi: 10.1016/S01607383(98)00082-6

Huang, S., \& Hsu, C. H. C. (2009). Effects of Travel Motivation, Past Experience, Perceived Constraint, and Attitude on Revisit Intention. Journal of Travel Research, 48(1), 29-44. doi:10.1177/0047287508328793

Kim, S. S., Kim, J. H., \& Ritchie, B. W. (2008). Segmenting overseas golf tourists by the concept of specialization. Journal of Travel \& Tourism Marketing, 25(2), 199-217. doi:10.1080/10548400802402958

Knežević Cvelbar, L., Dwyer, L., Koman, M., \& Mihalič, T. (2016). Drivers of Destination Competitiveness in Tourism: A Global Investigation. Journal of Travel Research, 55(8), 1041-1050. doi:10.1177/0047287515617299

Lamont, M., \& Jenkins, J. (2013). Segmentation of cycling event participants: a twostep cluster method utilizing recreation specialization. Event Management, 17(4), 391-407. doi:10.3727/152599513X13769392444666

Lew, A. A. (2013). A world geography of recreational SCUBA diving. In G. Musa \& K. Dimmock (Eds.), SCUBA diving tourism. London: Routledge.

Li, H., Pearce, P. L., \& Zhou, L. (2015). Documenting chinese tourists' motivation patterns. Paper presented at the Rising Tides and Sea Changes: Adaptation and Innovation in Tourism and Hospitality: Proceedings of the 25th Annual CAUTHE Conference, Gold Coast, Queensland.

Lucrezi, S., Saayman, M., \& Merwe, P. V. D. (2013). Managing diving impacts on reef ecosystems: analysis of putative influences of motivations, marine life preferences and experience on divers' environmental perceptions. Ocean \& Coastal Management, 76, 52-63. doi: 10.1016/j.ocecoaman.2013.02.020

March, R. (2000). The Japanese travel life cycle. Journal of Travel \& Tourism Marketing, 9(1-2), 185-200. doi:10.1300/J073v09n01_11

Mazanec, J. A. (1992). Classifying tourists into market segments. Journal of Travel \& Tourism Marketing, 1(1), 39-60. doi:10.1300/J073v01n01_04 
Meisel-Lusby, C., \& Cottrell, S. (2008). Understading motivations and expectations of SCUBA divers. Tourism in Marine Environments, 5(1), 1-14.

Musa, G., \& Dimmock, K. (2013). Introduction. In G. Musa \& K. Dimmock (Eds.), SCUBA diving tourism. London: Routledge.

Musa, G., Seng, W. T., Thirumoorthi, T., \& Abessi, M. (2010). The influence of SCUBA divers' personality, experience, and demographic profile on their underwater behavior. Tourism in Marine Environments, 7(1), 1-14. doi:10.3727/154427310X12826772784757

O’Neill, M. A., Williams, P., MacCarthy, M., \& Groves, R. (2000). Diving into service quality - the dive tour operator perspective. Managing service quality, 10(3), 131-140.

Oh, H., Assaf, A. G., \& Baloglu, S. (2014). Motivations and Goals of Slow Tourism. Journal of Travel Research. doi:10.1177/0047287514546228

Oppermann, M. (1995). Travel life cycle. Annals of Tourism Research, 22(3), 535-552. doi: 10.1016/0160-7383(95)00004-P

Oppermann, M. (1997). First-time and repeat visitors to New Zealand. Tourism Management, 18(3), 177-181. doi: 10.1016/S0261-5177(96)00119-7

Pabel, A., \& Coghlan, A. (2011). Dive market segments and destination competitiveness: a case study of the Great Barrier Reef ecosystem health. Tourism in Marine Environments, 7(2), 55-66.

PADI. (2017). Worldwide corporate statistics.

Panchal, J., \& Pearce, P. L. (2011). Health motives and the Travel Career Pattern (TCP) Model. Asian Journal of Tourism and Hospitality Research, 5(1), 51-.

Pansiri, J. (2014). Tourist motives and destination competitiveness: a gap analysis perspective. International Journal of Hospitality \& Tourism Administration, 15(3), 217-247. doi:10.1080/15256480.2014.925718

Paris, C. M., \& Teye, V. (2010). Backpacker motivations: a travel career approach. Journal of Hospitality Marketing \& Management, 19(3), 244-259. doi:10.1080/19368621003591350

Pearce, P. L. (2005). Tourist behaviour: themes and conceptual schemes. Clevedon: Channel view publications.

Pearce, P. L., \& Lee, U.-I. (2005). Developing the travel career approach to tourist motivation. Journal of Travel Research, 43(3), 226-237. doi:10.1177/0047287504272020

Pereira, M. A. M., \& Schleyer, M. H. (2005). A diver and diving survey in southern Mozambique. Coral Reef Degradation in the Indian Ocean, 184-192.

Poon, A. (1993). Tourism, technology and competitive strategies. Wallingford England: C.A.B. International.

Porter, M. E. (1990). The competitive advantage of nations. New York: Free Press.

Queiroz Neto, A., Lohmann, G., \& Scott, N. (2016). Destination competitiveness: theoretical gap, practical consequences. Paper presented at the CAUTHE 2016: The Changing Landscape of Tourism and Hospitality: The Impact of Emerging Markets and Emerging Destinations, Sydney. 
Ryan, C. (1998). The travel career ladder: an Appraisal. Annals of Tourism Research, 25(4), 936-957.

Sonmez, S. F., \& Graefe, A. R. (1998). Determining future travel behavior from past travel experience and perceptions of risk and safety. Journal of Travel Research, 37(2), 171-177.

Stolk, P., Markwell, K., \& Jenkins, J. M. (2007). Artificial reefs as recreational SCUBA diving resources: a critical review of research. Journal of Sustainable Tourism, 15(4), 331-350.

Thapa, B., Graefe, A. R., \& Meyer, L. A. (2006). Specialization and marine based environmental behaviors among SCUBA divers. Journal of Leisure Research, 38(4), 601-615.

Todd, S. L., Graefe, A. R., \& Mann, W. (2001). Differences in SCUBA diver motivations based on level of development. Paper presented at the Northeastern recreation research symposium, Bolton Landing.

Weaver, P. A., Weber, K., \& McCleary, K. W. (2007). Destination evaluation: the role of previous travel experience and trip characteristics. Journal of Travel Research, 45(3), 333-344. doi:10.1177/0047287506292702

Wernerfelt, B. (1984). A resource-based view of the firm. Strategic Management Journal (pre-1986), 5(2), 171-180.

Wilde, S. J., Cox, C., Kelly, S. J., \& Harrison, J. L. (2017). Consumer insights and the importance of competitiveness factors for mature and developing destinations. International Journal of Hospitality \& Tourism Administration, 18(2), 111-132. doi:10.1080/15256480.2016.1264902

Woodruff, R. B. (1997). Customer value: the next source for competitive advantage. Journal of the Academy of Marketing Science, 25(2), 139-153.

Worachananant, S., Carter, R. W. B., Hockings, M., \& Reopanichkul, P. (2008). Managing the impacts of SCUBA divers on Thailand's coral reefs. Journal of Sustainable Tourism, 16(6), 645-663. 